\title{
Healthcare practices for users suffering from violence: from invisibility to comprehensive (un)care
}

\author{
Práticas de saúde aos usuários em situação de violência: \\ da invisibilidade ao (des)cuidado integral \\ Prácticas de salud para usuarios en situación de violencia: \\ de la invisibilidad a la (des)atención integral
}

\author{
Patrícia Caprini Guzzo ${ }^{a}$ \\ Marta Cocco da Costab \\ Ethel Bastos da Silvac \\ Alice do Carmo Jahn ${ }^{d}$
}

\begin{abstract}
The aim of this study was to investigate practices of health professionals for users undergoing violence from perspective of comprehensive care. This study was based on a qualitative and descriptive research on graduate-level and technical health professionals who work in the Family Health Strategy programme in a northeastern municipality of Rio Grande do Sul. Data were collected by means of semi-structured interviews and analyzed using thematic mode. Results showed that these professionals do not utilize comprehensiveness to guide their care practices with users undergoing violence. Instead, they still work according to the biomedical model in which intervention is based on referring care to other sectors and the treatment plan. The study highlights the need for more appropriation and further discussion on practices regarding violence guided by the principle of comprehensiveness within the Family Healthcare team.
\end{abstract}

Descriptors: Nursing. Comprehensive care. Violence. Family health.

\section{RESUMO}

0 estudo teve como objetivo conhecer as práticas de cuidado dos profissionais da saúde a usuários em situação de violência, sob o eixo da integralidade. Pesquisa qualitativa, descritiva, com profissionais de saúde de nível superior e técnico atuantes na Estratégia de Saúde da Família de um município da região noroeste do Rio Grande do Sul, RS. Utilizou-se como instrumento de coleta a entrevista semiestruturada e analisou-se pela modalidade temática. Os resultados mostraram que os profissionais não utilizam a integralidade como eixo norteador de suas práticas de cuidado aos usuários em situação de violência, visto que ainda trabalham norteados pelo modelo biomédico, tendo os encaminhamentos para outro setor e o plano curativo como principais intervenções. 0 estudo mostra a necessidade de maior apropriação e discussão das práticas de cuidado a violência, orientadas pelo princípio da integralidade na equipe de Saúde da Família.

Descritores: Enfermagem. Assistência integral à saúde. Violência. Saúde da família.

\section{RESUMEN}

El estudio busca conocer prácticas de atención de profesionales de salud para usuarios en situación de violencia desde la perspectiva de la integralidad. Es un estudio cualitativo, descriptivo, con profesionales de salud de niveles superior y técnico, actores en la Estrategia de Salud de la Familia de un municipio del noroeste de Rio Grande do Sul - RS. Los datos fueron recolectados por entrevista semiestructurada y analizados por la modalidad temática. Según los resultados, los profesionales no utilizan la integralidad como norte de sus prácticas de atención para los usuarios en situación de violencia, porque todavía trabajan según el modelo biomédico, con prácticas encaminadas para otro sector y el plan curativo como principales intervenciones. El estudio muestra la necesidad de mayor apropiación y discusión de las prácticas de atención a la violencia orientadas por el principio de la integralidad en el equipo de Salud de la Familia.

Descriptores: Enfermería. Atención integral de salud. Violencia. Salud de la familia.
D0l: $\quad$ http://dx.doi.org/10.1590/1983Re Revista Gaúcha \subsubsection{1 \\ 1447.2014 .02 .4045}

\footnotetext{
Nurse. Multi-disciplinary resident in Family Health - FUMSSAR - Santa Rosa. Member of the Centre for Studies and Research on Collective Healthcare (NEPESC/UFSM). Palmeira das Missões, RS-Brazil.

${ }^{b}$ Nurse. PhD in Nursing. Adjunct Professor I of the Department of Health Sciences of the Federal University of Santa Maria - Campus Palmeira das Missões. Researcher and member of the Centre for Studies and Research on Collective Healthcare (NEPESC/UFSM). Palmeira das Missões, RS-Brazil.

' Nurse. PhD in Science. Adjunct Professor I of the Department of Health Sciences of the Federal University of Santa Maria - Campus Palmeira das Missões. Researcher and member of the Centre for Studies and Research on Collective Healthcare (NEPESC/UFSM). Palmeira das Missões, RS-Brazil.

${ }^{d}$ Nurse. Doctoral degree student DINTER NOVAS FRONTEIRAS UNIFESP/ANNA NERY/ UFSM. Assistant Professor III of the Department of Health Sciences of the Federal University of Santa Maria - Campus Palmeira das Missões. Researcher and member of the Centre for Studies and Research on Collective Healthcare (NEPESC/UFSM). Palmeira das Missões, RS-Brazil.
} 


\section{口INTRODUCTION}

In Brazil, violence is considered a complex and multifaceted phenomenon. Therefore, confronting this problem requires inter-sectional actions and acknowledgement as a healthcare and public health issue. Consequently, this study acknowledges violence as a phenomenon marked by complexity, polysemy and multiplicity, rooted in social and historical aspects that accompany the development of humanity ${ }^{(1)}$.

According to the 2011 violence map, 2.5 million people suffer physical abuse and violent murder rates increase in locations that were previously smaller. Homicide among the young population and men is also steadily increasing. When these facts are compared with other countries, Brazil ranks sixth in total homicide and juvenile homicide among the 100 countries investigated by the World Health Organization (2).

Care for morbidity caused by violence is provided in the health sector and one of the user admission channels is the Family Health Strategy (ESF), considered a model of care reorganization for users of the Unified Health System (SUS). It has also been the privileged locus to work with this phenomenon, considering that its objectives are the possibility of new care practices for violence based on the approximation of users and professionals, and territoriality. As it is a new care model, the ESF allows professionals to work with the topic of violence in a preventive and promotional manner.

In this sense, the ESF is governed by the principles and guidelines of the Unified Health System (SUS), in which comprehensiveness is legitimized by the Federal Constitution of 1988 as a principle of the SUS in Article 198, Item II that, since then, is part of the healthcare reform and the care quality assessment process ${ }^{(3)}$.

Another possibility of analysing healthcare practices in the field of violence is the "provocation" of acknowledging them, considering comprehensive care from the perspective of four dimensions: the development of promotion and prevention actions; guarantees of the three levels of care; articulated promotion, prevention and recovery and the comprehensive approach of individuals and access as the first step towards comprehensiveness. Consequently, integration of services in the form of a network is also required to respond to the suffering of others, thus modifying basic technical procedures and actions ${ }^{(4-6)}$.

Although comprehensives is considered the structural priority of healthcare actions in the SUS, professionals of the ESF tend to conduct healthcare practices that target the resolution of user symptoms without considering their lifestyle, social relationships and characteristics that can determine their health condition. Lightweight and heavyweight technologies are adopted as care to the detriment of the acknowledgement of user demands that can be unrelated to diseases, which reinforces curative-care actions ${ }^{(7)}$. When the problem is violence, this situation becomes invisible and solutions are referred to other sectors, as healthcare is not responsible for solving problems of a social order ${ }^{(8)}$.

In this perspective, based on the revision of literature and empirical data to obtain knowledge on the violence identified by family healthcare professionals during their daily work, and to shed light on this problem in the field of health, the following guiding questions were created: How do family healthcare professionals identify and proceed when confronted with the problem of violence in healthcare services, in the context of comprehensiveness? What are the difficulties that family healthcare professionals face when dealing with violence? These questions were used to establish the objective of this study: to obtain information on the practices of healthcare professionals when dealing with users who are suffering from some form of violence, from the perspective of comprehensive care, in a municipality in the north-eastern region of the state of Rio Grande do Sul.

\section{METHODOLOGY}

To reach the proposed objective, the exploratory, qualitative research method was adopted ${ }^{(9)}$. This study was conducted at the Family Health Strategy (ESF) units in a municipality in the north-eastern region of the state of Rio Grande do Sul.

A total of 12 professionals participated in the study, all of which worked at the Five ESF of the municipality, being that 4 were nursing technicians, 4 were nurses, 2 were dentists and 2 were physicians. Inclusion criteria were: practicing at the ESF units for more than six month and actively practicing during the data collection period. Exclusion criterion was: absence due to medical leave or holidays. Response saturation was used to determine whether the number of participants was sufficient ${ }^{(10)}$.

For data collection, the adopted instrument was semi-structured interviews, which corresponded to characterization of the professionals and a combination of open and closed questions, in which the interviewee could talk about the topic without feeling restricted to the question ${ }^{(10)}$.

Interviews were conducted in a suitable room in the ESF units and recorded in MP3 format to correctly register statements for analysis. To preserve the identity of participants, each interviewee was respectively attributed letters "E" for 
nurse, " $M$ " for physician, " $D$ " for dentist and "TE" for nursing technician, followed by the sequence number of each professional category according to the order of interviews. Data were collected between July and September 2011.

Data were subjected to the thematic content analysis proposed by Minayo ${ }^{(9)}$. After interviews were transcribed, they were read and assessed to establish overall meaning, and all common topics and meanings were classified under the same central theme ${ }^{(9)}$. Subsequently, the following thematic axis was constructed: Healthcare practices for users suffering from violence - elements of comprehensive (un) care with sub-axes: Care practices centred on biological aspects, Fragmented care practices and lack of preparation when caring for users suffering from violence.

Standards of Resolution 196, of November 10, 1996 were observed, for the conduction of research on human beings, and the study was approved by the Research Ethics Committee of the Federal University of Santa Maria (UFSM) under process 23081.005747/2011-68.

\section{RESULTS AND DISCUSSION}

\section{Healthcare practices for users suffering from violence - elements of comprehensive (un)care}

\section{Care practices centered on biological aspects}

Findings of this study show that care practices for users suffering from violence are centred on aggravations that result from physical injuries. Healthcare practices were generally governed by events of a physical order and on clinical diagnosis, with observance of injuries and organic dysfunctions. Events that are unrelated to clinical findings are excluded from diagnoses and the treatment plan ${ }^{(8,11)}$.

Most statements by professionals of the investigated healthcare teams showed that during their daily activities, physical violence is prioritized. This may occur because physical violence has explicit signs and symptoms, such as "physical abuse, bodily harm or physical contact," or that it reinforces the centrality of healthcare actions in the realm of the biological paradigm for the recognition of violence ${ }^{(12-13)}$.

[...] reports of signs, during the physical exam, in the inju$r y$, contusions or contuse cuts [...] children with fractured arms [...] violence against the elderly [...] you start to think the bruises are suspicious, especially in bed-ridden patients (M1).

[...] one seventy-year-old lady referring back pain, I noticed she was very tense [...] then I realized she had a huge bruise on her back, her husband had hit her with a stick, at home, her husband had broken a chair on her back [...] a local patient, once she came with a broken arm, another time with a cut on her face (M2).

In this sense, biologicism in healthcare interventions during the practice of the professionals of this study is based on dealing with and treating the lesion, without considering the motives that caused it. Knowing aspects that involve the body and most frequent locations of injuries caused by physical violence is important when there are suspicions regarding a case, but the observed dimensions must transcend purely biological aspects. Actions such as listening to users, proposed in the principle of comprehensive care, seek to identify unmet social and cultural demands and policies that generate violence that, when tackled in a confrontational project with users, move towards solving these problems ${ }^{(14)}$.

Comprehensiveness is a guiding principle of the SUS that seeks to promote service integration by means of care networks, thus requiring the humanization of services offered to users suffering from violence and from healthcare professionals. Tools include the use of lightweight technology provided in their approaches, guaranteeing accessibility, resolvability or the necessary referrals of users in the cases of violence ${ }^{(4)}$.

The reorganization of services in the perspective of comprehensiveness has proved to be one of the greatest challenges of healthcare work, namely because most professionals are trained according to the Cartesian and physician-centred model. Care provided to users suffering from violence is therefore based on the biological model and specialities, without contemplating the dynamics, relationships and complexities that involve individuals ${ }^{(15)}$. The following statements support these findings:

\section{[...] care is provided per se [...] (M1).}

[...] a young woman [...]came in with wounds and abrasions, no one knew what had happened [...] she came in several times to dress her wounds (victim of domestic violence) (TE1).

These statements attest the "medicalizing" dimension when confronted with the problem of violence. This reflects excessive medical interventionism on the bodies and in the lives of victims, which is related to medical power. Professionals ultimately intensify the disuse of comprehensiveness when caring for patients and the team cannot meet the demands and needs of this population ${ }^{(15-16)}$. 
The practices of healthcare professionals that target users suffering from violence in basic care do not observe the comprehensive care established by the guidelines and principles of the SUS. Firstly, statements showed that their conduct when confronted with cases of violence varies considerably, and "[...] each healthcare professional creates his or her own strategy to deal with violence during their daily routine, according to individual conceptions ${ }^{\prime \prime(18)}$. This is evident in the following statements:

Our conduct varies, we try to calm the patient down, help him or her rely on professional ethics [...] (M2).

[...] we try to talk to the patient, give advice and listen [...] (TE1).

You have to interview others [...] I notify, talk [...] (E1).

These statements reveal attempts to insert listening and dialogue with users suffering from violence in the care practice. A study showed that when relationship-based tools are used by healthcare professionals with families that are susceptible to violence, especially during home visits, they help to identify family violence, chiefly domestic violence. Patients realize they are not alone and that these professionals are familiar with their problems and assume responsibilities ${ }^{(14)}$.

Statement analysis showed that this problem is not mentioned in team meetings and that intervention, confrontation or prevention actions are not organized for these teams. The topic of violence is only discussed when it is part of a biological event and is mentioned by a team member.

[...] In our meetings, case discussion is protocol, but to date, we have not had a specific case of violence (D2).

[...] we actually try to do something about it, but it is usually an external event, unless the council presents a situation [...]but from the team itself, we don't really mention that work topic (TE2).

The fact of not routinely discussing this phenomenon in the team results in individualized and ineffective care practices, which in turn lead to (re) victimization of users, which is the product of the "instituted" form of neglect of these situations in healthcare services. In some cases, this phenomenon is only specifically integrated to care actions and remains obscure, resulting in the continuance of violence. To improve integration in the team, cases of violence must be discussed to create instruments that help professionals deal with this topic and subsequently improve the quality of care provided to the victims of violence.

\section{Fragmented care practices and lack of preparation when caring for users suffering from violence}

In addition to the difficulty of inserting relationship-based elements in care practices, the participants had difficulties in coping with their limitations, which transforms them into human impotencies ${ }^{(18)}$. Moreover, as they do not acknowledge this problem as being part of the field of healthcare, they tend to refer users to other services and exempt themselves from the responsibility of confrontation and intervention.

\section{[...] he suspected violence and contacted child services [...] (M1).}

[...] we advise them, we don't order them, to seek the authorities, to give their account, so their situation does not get worse [...] lots of them already come here with police report in their hands (TE4).

According to the WHO $(2002)^{(19)}$, violence requires the intervention of several sectors to solve the problem, and these professionals are adopting measures that comply with recommendations of this organization. Furthermore, there is the notion that comprehensiveness can be constructed from the moment in which users suffering from violence are offered guaranteed care by the primary care system. However, results show that this does not always occur and care practices follow an interrupted path, in which users receive care from several disconnected sectors and work processes are divided into fragmented activities ${ }^{(18)}$.

Findings showed a fragmentation of practices that can be related to the naturalization of violence and lack of preparation of healthcare professionals to cope with these users, which is the result of fragile policies and scarce institutional involvement. In cases of violence, the creation of bonds is essential for collaboration and co-responsibility of the team and users ${ }^{(18)}$.

Furthermore, the difficulty to gain access to specialists, which is mostly due to long waiting lists and a shortage of professionals, most certainly affects the bond between teams and users, and may be interpreted as lack of commitment of the healthcare service when solving this problem of users. Professionals must understand that isolated actions are not effective when dealing with violence ${ }^{(7)}$. 
Referrals without exhausting all diagnosis possibilities in the ESF shows a lack of responsibility of the team when caring for users suffering from violence. This does not mean that referring users to other support services is not necessary, but it highlights that the support provided by teams is essential for the provision of care and follow-up with other specialities of the system ${ }^{(15)}$.

In this perspective, teams should not view specialized services as the only form of solving existing cases. However, when the topic is violence, more difficulties arise, as these services are not always capable of providing support and continued care ${ }^{(14,17)}$.

To work in a healthcare network requires more than the mere articulation of services. Services must develop their activities and these activities must result in a common denominator that should be resolvability for users/subjects. In this sense, studies suggest horizontality, the separation of resources and information, that is, new forms of creating partnerships as basic conditions for building networks $(17,20)$.

The principle of comprehensiveness can be developed in the healthcare sector when the team inserted in the ESF is truly involved with the proposal of change, especially in the care model, considering that comprehensiveness requires venturing beyond pathological signs and symptoms by listening and dealing with complaints brought by users that seek healthcare services. In this scope, "comprehensiveness in healthcare addresses the need for articulation between prevention and care practices, necessarily involving the integration between health services and institutions" (18:12).

Analyses showed that the professionals do not feel they are prepared to deal with aspects of violence, which transcend that which is biological.

There is some difficulty because we can't get too familiar with the patient's history [...] to date, I have never been trained on how to deal with violence [...] (M2).

[...] a flu, an epidemic, we are trained to deal with that, for those things that involve extra things (Violence) that do not involve entirely physical aspects, we often have difficulties (M1).

This lack of preparation of professionals of the ESF when confronting cases of violence was also identified in a study conducted in basic care services in the city of São Paulo. Moreover, these professionals are prepared to tend to users from events that do not involve extra issues such as flu, leprosy, diabetes or high-blood pressure. However, they did not use comprehensiveness as their guiding principle in care practices for users suffering from violence, that is, they were not accustomed to caring for individuals as a whole being, only their pathology ${ }^{(8)}$.

Caring for users that suffer from violence requires a lot more than the basic care offered by the healthcare service, referrals and medicalization. During the provision of care, professionals must also consider how users feel about the aggression and what it represents in their lives ${ }^{(15)}$.

When caring for victims of violence and the aggressor, the parties involved must not be judged, as the responsibility of professionals is to advise these individuals so they can change their behaviour, rather than to make decisions for them. In order to work from the perspective of comprehensive care, there must be changes in the individual and collective care practices in relation to valuing the creation of bonds, support, autonomy and subjectivity in healthcare work, and consider the individual needs of each subject ${ }^{(7,14)}$.

When professional practice is governed by the perspective of comprehensiveness, it is very important that these practices are not limited to a biologistic approach, and that they include cultural aspects, social life and family context. Contact of professionals with users enables familiarity with their needs and the corresponding support, leading to the construction of continued care and joint responsibility for building the treatment plan ${ }^{(20)}$.

\section{FINAL CONSIDERATIONS}

This study provided insight into the care practices of professionals of family health teams when confronted with users that are suffering from violence in the perspective of comprehensive care. It showed that actions are restricted to individual clinical care that focuses on treating injuries and is therefore pathologizing and medicalizing, founded on the principles of the biomedical model.

Results revealed that professionals have made attempts based on listening, providing support, assuming joint responsibility and bonding, all of which may help users to distance themselves from these violent situations, although these professionals do not always feel prepared to deal with this problem.

It is therefore concluded that healthcare professionals can be used as instruments to create a training strategy based on the principle of comprehensive care. Discussions and reflection on care practices for users suffering from violence in the ESF may help to initiate care that can demystify this problem and help overcome the prejudice, and provide care that is more efficient and resolutive.

It should be noted that this study was conducted in a specific reality and context, which may not represent generalization of data, although it does reveal important infor- 
mation that can be used to create strategies and actions in the work process that may be expanded to achieve humanized and integral healthcare. This study also contributes to research and education by adding fundamental elements to rethink the professional training process in healthcare, especially of nursing professionals, based on the principles and guidelines of the SUS.

It is also important to create a dimension of joint responsibility of all citizens when confronting all forms of violence, which should stimulate the use of comprehensiveness on care practices. The construction of local public policies that target violence awareness and prevention is also suggested, to meet the needs of victims, aggressors and family members, and guarantee resolution and the effective operation of support networks.

\section{REFERENCES}

1. Minayo, MCS. Violência e saúde. Rio de Janeiro: Fiocruz; 2006.

2. Waiselfisz, JJ. Mapa da violência 2011: os jovens no Brasil. São Paulo: Instituto Sangari; Brasília, DF: Ministério da Justiça; 2011 [citado 2014 jan 12]. Available in: http://www.mapadaviolencia.org.br/pdf2011/MapaViolencia2011.pdf.

3. Ministério da Saúde (BR). Cartilha da Política Nacional de Humanização, Brasilia; 2006.

4. Hartz ZMA, Contandriopoulos AP. Integralidade na atenção e integração de serviços de saúde: desafio para avaliar a implantação de um "sistema sem muros". Cad. Saúde Pública. 2004;20 Supl 2:S331-6.

5. Mattos RA. Os sentidos da integralidade: algumas reflexões acerca de valores que merecem ser defendidos. [citado 2011 ago 25]. Available in: http://www. uefs.br/pepscentroleste/arquivos/artigos/os_sentidos_integralidade.pdf.

6. Conill EM. Avaliação da integralidade: conferindo sentido para os pactos na programação de metas dos sistemas municipais de saúde. Cad. Saúde Pública. 2004 set-out; 20(5):1417-23.

7. Mattioni FC, Budô MLD, Schimith MDO. Exercício da integralidade em uma equipe da estratégia saúde da família: saberes e práticas. Texto Contexto Enferm. 2011 abr-jun; 20(2):263-71.
8. Kiss LB, Schraiber LB. Temas médico-sociais e a intervenção em saúde a violência contra mulheres no discurso dos profissionais. Ciênc. Saúde Colet. 2011;16(3):1943-52.

9. Minayo MCS. 0 desafio do conhecimento: pesquisa qualitativa em saúde. 11. ed. São Paulo: Hucitec; 2010

10. Fontanella BJB, Ricas J, Turato ER. Amostragem por saturação em pesquisas qualitativas em saúde: contribuiç̧ões teóricas. Cad. Saúde Pública. 2008;24(1):1727.

11. Cocco M, Silva EB, Jahn AC. Abordagem dos profissionais de saúde em instituições hospitalares a crianças e adolescentes vítimas de violência. Rev. Eletr. Enf. [Internet]. 2010;12(3):491-7. Available in: http://www.fen.ufg.br/revista/v12/ n3/v12n3a11.htm.

12. Rosa R, Boing AF, Schraiber LB, Coelho EBS. Violência: conceito e vivência entre acadêmicos da área da saúde. Interface: Comunicação Saúde Educação, 2010 $\mathrm{jan} / \mathrm{mar} ; 14(32): 81-90$.

13. Nunes $C B$, Sarti CA, Ohara CVS. Concepções de profissionais de saúde sobre a violência intrafamiliar contra a criança e 0 adolescente. Rev Latino-Am Enfermagem. 2008 jan-fev;16(1):136-41. Available in: www.eerp.usp.br/rlae.

14. Luz AMH, Mancia JR, Motta MGC. As amarras da violência: a família, as instituições e a enfermagem. Braśilia: Associação Brasileira de Enfermagem; 2004. $175 p$.

15. Ferreira RC, Chirelli MQ, Pereira AG. Abordagem psicológica na atenção básica em saúde: da fragmentação à integralidade. Rev Bras Educ Med. 2011;35(2):17785.

16. Bonfada D, Cavalcante JRLP, Araújo DP, Guimarães J. A integralidade da atenção à saúde como eixo da organização tecnológica nos serviços. Ciênc. Saúde Colet. 2012; $17(2): 555-60$

17. Lima MADS, Ruckert TR, Santos JLG, Colomé ICS, Acosta AM. Atendimento aos usuários em situação de violência: concepções dos profissionais de unidades básicas de saúde. Rev Gaúcha Enferm. 2009 dez;30(4):625-32.

18. Costa AM. Integralidade na atenção e no cuidado a saúde. Saúde Soc. 2004;13(3):5-15

19. Krug EG, Dahlberg LL, Mercy JA, Zwi AB, Lozano R, editors. World report on violence and health. Geneva: World Health Organization; 2002.

20. Costa MC, Lopes MJM. Elementos da integralidade nas práticas profissionais de saúde a mulheres rurais vítimas de violência. Rev Esc Enferm USP. 2012; 46(5):1088-95
Author's address:

Marta Cocco da Costa

Av. Independência, 3751, Vista Alegre

98300-000, Palmeira das Missões, RS

E-mail: marta.c.c@ufsm.br
Received: 11.06.2013

Approved: 17.03.2014 